\title{
The Effect of Brand Image And Quality Of Educational Services On Customer Satisfaction
}

\author{
Connie Chairunnisa \\ Faculty of Economy and Bisiness \\ University of Muhammadiyah Prof.DR.HAMKA, Jakarta \\ Email: zusconnie@uhamka.ac.id
}

\begin{abstract}
This study aims to provide information on the influence of brand image, the quality of education services on consumer satisfaction. This research uses survey method with path analysis technique, with a sample of 244 respondents. The results of the study prove that (1) there is a positive and significant influence between brand image on customer satisfaction, by $66.7 \%$ (2) there is a positive and significant influence between the quality of education services on customer satisfaction by $71.4 \%$ (3) there positive and significant influence between brand image and education service quality on customer satisfaction by $78.1 \%$. In order to encourage the level of customer satisfaction, the Faculty needs to pay attention to the expectations and complaints of its customers, and continue to improve the quality of education services.
\end{abstract}

Keywords: Brand image, service quality, customer satisfaction.

\section{BACKGROUND}

The key to the success in education world is the virtuous value of educational services since itshows the potential of the teachers, pupils, and leadership of the school principal. Based on the Law of the Republic of Indonesia Number 20 of 2003 Chapter I Article 1 paragraph (1) it is mentionedthat Education as conscious and planned effort is done to create an atmosphere of studying and learning process so that learners keenly develop their potential to have spiritualpower, controlling, noble character, as well as the skills needed by him, the people of the nation, and the State.

In learning, there is a process of transferring the information and knowledge thoroughly. By way of education, it is wished to create humans who will bring this nation to become better. Besides, through education society will be more advanced which eventually creates public awareness in order that it will not only gradually change this nation from the attitude of slavery and submission to the attitude of independence but also have self-esteem parallel to the other nations in the world. Building a whole person is the best goal in educational obligations. Whole man is the man who could optimize all potential sides (physicaland mind) or in other words blend the elements of faith and piety with science and technology. Economic college yet almost in all elements of human life then globalization also affects the college either sooner or later.

For people who choose to continue and complete their education to the highest level, then they will be faced with various choices and problems. Choosing to continue education to college, the community will be faced with a variety of college options. Moreover, society will also be faced with so many considerations to be considered. Based on a survey conducted by (Indrajit, 2013) suggests there are 5 dimensions of the meaning 
of universities or institutions in the field of education, namely: the scientific dimension (science and technology), educational dimension (higher education), social dimension (community life), corporate dimension (unit and organization), and the ethical dimension (requested to be replaced because it is under 10 years).

The demands on universities today are not only limited to the ability to produce academically measured graduates but also the whole program. In addition, the higher education institutions have to be able to prove the high quality supported by the existing accountability so that it can lead to a variety of college choices as consideration for prospective students (Yani, 2011). Of course, taking some choices with those considerations is not easy and it requires proper thinking based on consideration.

Faculty of Economics and Business UHAMKAitself has five courses and the tendency of the community to choose the study program vary widely as listed in table 1 .

Table 1. Tendency to select study program.

\begin{tabular}{clcccccc}
\hline No. & \multicolumn{1}{c}{ Study program } & 2012 & 2013 & 2014 & 2015 & 2016 & Total \\
\hline 1. & Accounting & 229 & 196 & 205 & 258 & 216 & 1.104 \\
2. & Management & 152 & 214 & 240 & 307 & 284 & 1.197 \\
3. & Taxation (Diploma) & 35 & 30 & 38 & 48 & 54 & 205 \\
4. & Accounting (Diploma) & 43 & 14 & 26 & 25 & 27 & 135 \\
5. & Islamic Economics & - & - & - & 16 & 45 & 61 \\
& $\quad$ Total & 459 & 454 & 509 & 654 & 626 & 2.702 \\
\hline
\end{tabular}

Data source: UHAMKA Academic Information System 2017

\section{THEORETICAL REVIEW}

According to (Sharifah and Philip, 2014), a good brand image in a school business will have an effect on the satisfaction of the school students in the place, thus influencing him to recommend to his colleagues to study at the venue. The brand image of the college will also be considered by prospective students. The selection of universities with good brand image will be prioritized in order to fulfill their needs because good imaging of a college will both get a positive value in the eyes of consumers and give an idea of the quality of the college. Image (image) can be interpreted as a reputation of the institution in the eyes of the public. For people who choose to continue and complete their education to the highest level, then they will be faced with various choices and problems. Choosing to continue education to college, the community will be faced with a variety of college options. In addition, the community will also be faced with so many contemplations that should be considered including the excellence of university as higher education institution.

Factually the quality of educational services is also a significant consideration of customer satisfaction. According to the variable of educational service quality, the statement in the questionnaire of data collection shows that many of the 3rd semester students from 5 study majors of Faculty of Business and Economics UHAMKA chose "Agree" (A). That means the facilities provided by the campus are in accordance with customer expectations. However, this research could also be an input for the future improvement of FEB UHAMKA which can be seen from the student on answering the questionnaire of customer satisfaction variable. Based on 33 statement items, Strongly Disagree (SD) answers were related with parking facility and sport facility. This means 
that parking and sports facilities need to be improved both in the campus of Pasar Rebo and the campus of Limau.

According (Kotler and Keller,2012) a name, term, sign, emblem or design, or combination thereofplanned to classify the goods or services of one of the sellers or groups of sellers and differentiate them from competitors is clarified as brand. The research done by (Shammot,2011) factor fee and info scattered adversely affecting student Jordan to choose the University private.Based on that opinion, we know that the brand image is a set of brand associations that give rise to a belief and stick in the minds of consumers.

According to the research by (Sharifah and Kitchen, 2014), there are three factors to measure the brand image of educational institutions namely (1) Cognitive brand aspect; (2) Affective brand aspect, and (3) Corporate brand image. Cognitive brand aspect consists of functional/qualified attributes of the school service process. Their aspects are like administrative and general factors, faculty, communication, physical facilities and innovation. Affective brand aspect is described as affective and emotional constructexpressing the result of service process (technical quality), whereas corporate brand image is more influenced by intangible factors.i.e. aspects that are more influenced by emotional factors. An important component is the quality of the goods themselves.Research done by (Fure et al., 2015) declare that simultaneous brand image, the product quality and price influential significant against the purchase of consumers. In percial brand image and the product quality influential significant against the decision of the purchase of consumers and variable price influential not significant.

Research done by (Patel and Patel, 2012) positive statement, advise, specialties offered, the name, and brand image, the as well as the location, factor that may affect the students choose the program master was aninGujaratis. also concluded that feelings about product, brand and the intention to buy are the measurements that underlie the brand loyalty itself. According to Aaker (2004), a strong sense of self-confidence in consumers or customers is a belief that the decision on the purchase he or she took is true. In can be concluded thata person's conscious plan to buy a particular brand is called purchase intention (Spears and Singh, 2011).Factually, it can be seen from the questionnaire answersof respondents (students) about brand image variable to the statement of studentcentered learning process (there is discussion during the lecture). Respondents answered Agree (A) as much as 68\%, and Strongly Agree (SS) as much as $16.9 \%$, and the rest as much as $13.3 \%$ answered Hesitant $(\mathrm{H})$. This means that in fact customers (students) are satisfied with brand image of UHAMKA.From various opinions above about the theory of brand image, it can be summarized as the synthesis that aset of brand associations creating firm belief and embedding consumer mind is known as the brand image with dimensions of 1) Cognitive brand aspect which indicators are: (1) functional attributes/quality of school service process; (2) aspects of general administration factor; (3) teaching staff; (4) communications; (5) physical facilities; and (6) innovation. 2) Affective brand aspect which indicators are: (1) the nature or character being produced; and (2) the quality being produced; 3) Corporate brand image with dimension is: 1) intangible aspect which indicators are: (1) the accreditation value of educational institutions; and (2) promotion.

Quality is often interpreted as a state of things or position compared to something else such as comparing the quality of educational services of some Primary Schools to a set standard. When it is more than standard or equal to the standard, the education service is called competent or qualified. 
The existence of the quality of educational services is a guide to the nature of the services provided that match or exceed the expectations and satisfaction of its customers either express or implied. School customers are categorized into two types: internal customers (Educators/Teachers/Lecturers and Staff/Secretariat) and external customers (Students, Parents, Government and Society) whoare also called stakeholders.

According to (Goetsch and David, 2016) on the quality of educational services,something dynamic associated with products, services, people, and environments that meet or exceed expectations is known as quality. Furthermore, it is found that quality is performance to the standard yearned by the customer.

According to(Edward Sallis,2003) quality indicates the nature of the "good" degree of a good or service that is produced or supplied by a particular criteria institution and as something that satisfies the customer and meets their needs and wants. In Educational context, the idea of quality requires education providers to understand and apprehend that educational institutions do not produce goods, but services or education services. Learners are not the products of educational institutions though the educational services they received will make them qualified graduates. This means that the product of goods is very different from the product of service. It is no exaggeration to say that the primary purpose of a school is to meet the needs and desires of learners as the main stakeholders. This does not mean that other stakeholders are ignored. However, learners become the reason why an educational institution is established and is maintained its reputation. In the learning process, learners are conditioned in a learning environment that ensures the achievement of quality.

In the end it needs to be emphasized and to be known that the general goals which will be achieved by every quality educational institution are to produce qualified graduates. Education customer satisfaction goes hand in hand with dissatisfaction. This talks about the customer's response to evaluation and the way of public as well as college on perceiving inadequacy between previous expectations and accepting output of actual performance. So, the satisfaction of society and college is an emotional response felt by the community when they get the experience of sending their children to school. Opinion by (Kotler, 2011) said that the raw materials to produce services are people who have characteristics that are different from each other. The saying goes that no human has the similarity even for the twins. That is what makes the basis that education services are different from one another. By looking at these characteristics, education service is a process after doing interaction with the liaison which is greatly influenced by who, when and wherever the service is produced.

Zamroni, (2011) considers that quality improvement could be done through the TQM model where school emphasizes the role of school culture within the framework of The Total Quality Management (TQM) model. This theory enlightens that school quality includes three abilities namely: academic, social, and moral skills. Based on the theory, three variables namely school culture, teaching-learning process, and school reality will determine the quality of school. Furthermore, school culture is described as the values, habits, ceremonies, slogans, and behaviors that have long been established in schools and passed from one generation to the next, both consciously and unconsciously. The behavior of all components of the school: teachers, principals, administrative staff, students and parentsis believed as an effect of the school culture. Conducive culture to quality improvement will encourage citizens' behavior towards improving the quality of schools; 
otherwise non-conducive cultures will hamper efforts towards improving the excellence of schools.

Furthermore, cultivating the excellence of schools suggested by (Danim, 2007) involves five dominant factors, namely: (1) Leadership of Principal; have a clear vision of work, (2) Students; the approach that must be done is the power on the students, (3) Teacher; fully teacher engagement, (4) Curriculum; the existence of a curriculum that remains effective yet dynamic so that the goals could be achieved maximally; (5) Cooperation networks which are not only limited to school and community environment but also with other organizations such as companies so that the output of schools can be absorbed in the world of work.

Mean while and Agata Pradela, (2015) stated that service quality dimension based on SERVQUAL research presents five dimensions as customer criterion in assessing service quality (education), namely (1) Tangible; they are such as physical facilities, equipment, employees; (2) Empathy; it includes the simplicity of conceiving customer needs and establishing relations with good communication; (3) Responsiveness; the desire of the staff to assist the customers and offer services with awareness, (4) Reliability; ability to deliver promptly and satisfactorily promised services, (5) Assurance; the ability and courtesy of serving customers, and the credible nature of the staff, free of danger, risk, and hesitancy.

Based on the aforementioned opinions can be deduced as synthesis what is meant by the quality of education service is the effort of the educator and the education staff in implementing the service to the students, parents and other society which is their responsibility based on the quality and the result of their works with dimensions of (1) Tangibles, with indicators (a) the use of infrastructure; (2) Empathy, with indicators (a) social interaction, (b) understanding of learners; (3) Responsiveness, with indicators (a) speed of response in service; (4) Reliability, with indicators (a) accuracy, (b) reliability; (5) Assurance, with indicators (a) convenience.

The importance of customer satisfaction relates to the increasingly keen competition to gain customers, as well as the level of corporate profits and losses. In fulfilling customer satisfaction, we need to conceive the components related to consumer contentment. Basically a situation where consumer needs, wants, and expectations can be met through the product consumed is simply defined as consumer contentment. Furthermore, Other again said by (Rossi et al., 2015) products that may influence to the intent of purchase, and brand image, have no effect on the intent of purchase.

Customer satisfaction by (Kotler and Philip, 2011) is the feeling of pleasure or disappointment of a person by comparing between products/services expected and products/services received. One of the factors that determine customer satisfaction is customer perception about the quality of services, products, prices and factors that are personal and temporary (Rangkuti, 2011).

According to (Halim, 2014) there are several characteristics of customers needed to be observed related with customer satisfaction in the implementation of Education such as: (a) Customer who is very thorough; (b) The main drivers of customer satisfaction as well as the primary drivers of internal and external customers, education management, quality of alumni, service quality, competitive pricing, emotional factors (pride, confidence, success symbols and the like), and easy access to get information on the progress of learners; (c) Relation of dimensions to customer emotions; (d) Strategies to encourage and resolve customer complaints; (e) Warranty to Customer; (f) Loyal customers, customers 
who get repeated satisfaction will turn into loyal and loyal customers; (g) The empowerment of customers, faculty and employees as internal customers need to be empowered to achieve job satisfaction; (h) Faculty Leadership as per customer expectations. This can be seen from the facts of the students in answering the questionnaire of customer satisfaction variable to the statement related with the Dean (Faculty/Department) and the lecturers provide the service friendly and politely in the learning process and guidance. From 33 items of statement, students answered Agree (A) as much as 1\%, and SS (Strongly Agree) as much as $19.1 \%$, and the rest of $12.7 \%$ (Doubtful). This means customer satisfaction (student) on service quality still needs to be improved again. Customer satisfaction can be interpreted as the realization of the response; it is an assessment of the product or service characteristics at a very pleasant or very unpleasant level. Customer satisfaction is a blend of expectation and desire.

Research done by (Patel and Patel, 2012),positive statement, advise, specialties offered, the name, and brand image, the as well as the location, factor that may affect the students choose the program master was an in Gujaratis. A positive or negative respond from consumers about the value of something it receives, as a result of the use of a number of things that have been given by an Institutionis known as customer satisfaction. Customer satisfaction can also be interpreted as the feeling of someone who was never imagined before a product or service that is in accordance with his expectations. Such a situation can only be achieved when a company or institution can provide a product or service based on an analysis of consumer needs and expectations at this time and anticipate the development of consumer hopes and needs in the future.

In relation to customer satisfaction is customer complaints. It is basically an information submitted by the consumer in the hope that the information can be followed up by the service provider. Thus consumers basically expect a follow-up of their complaints. Appropriate follow-up is basically an asset of marketing. With the benefit of it, the consumer will become loyal and it will increase the market share.

Most consumers leave the company/institution because they feel their problems continue without any effort from the company/institution to overcome them. This can happen because the company is not aware of any problems that are being experienced by the customer, or the company knows, but just lets the problem persist.

Many managers of the Education Institute believe that customer satisfaction is positively correlated with customers' buying behavior. This assumption of development is less reliable, where there is a gap between the level of satisfaction and repeat purchases. As (Asghar, 2011)points out from the results of the survey that $85 \%$ of the customers of an organization expressed satisfaction, but showed a desire to switch to other suppliers. When the size of customer satisfaction is less reliable, then the measurement that needs to be done is by what we know with customer loyalty.

In this case, Educational Institutions including the University may be viewed as an industry or service company for producing products that are not physical creations such as goods or products. Service industry has specific characteristics as follows:(1) Customer desires and performance standards are often difficult to identify and measure. Particularly because customers who define their desires and each customer have different desires; (2) To provide services usually requires a high level of customization; (3) The output of the service system is invisible, so the measure of service quality often cannot be measured by technical specifics as in the product; (4) Services are produced and used simultaneously or at once, so in this sector the key to product success lies in the time the customer is dealing 
directly with the performance of the product; (5) Customers are often involved in the service delivery process and are present when the process is being created; (6) Services usually require more manpower, so the key to success of this sector lies in the quality of its human resources. (HR); (7) Many service companies have to manage large numbers of customers, so speed is the key to success and process error should be avoided.

Based on those explanations, it can be synthesized that customer satisfaction is the customer's perception of the difference between "reality" and "hope" on using services/products. That is if the reality is better/higher than hope then customer is content. Conversely, if the reality is worse/lower than expectation then customer will be disappointed, with dimension: 1) Consumer perception which indicators are: (a) service quality, (b) result given, (c) competitive price; 2) Emotional factors which indicators are: (a) pride; (b) confidence, (c) symbol of success.

\section{METHOD}

This research method refers to research that had been done by (Ria andZahrid,2012) using quantitative method through causal survey which was collecting data from member of population, as it was, without treatment in order to know the real condition of population related to variable that was studied. This survey approach was done to get the data from a certain place that was natural (not artificial) though researchers did treatment in data collection by circulating surveys. The design of this research was research design with hypothesis testing.Data processing and data analysis usedwas statistics which played a role to formulate theoretical model, formulation of hypothesis, development of data collection tools, data analysis, preparation of research design and data processing. There were three variables being studied: Customer Satisfaction called dependent variable or endogenous $(\mathrm{Y})$, Brand Image as independent or exogenous variable $\left(\mathrm{X}_{1}\right)$ and Quality of Education Service as independent or exogenous variable $\left(\mathrm{X}_{2}\right)$. Therefore, this study conducted correlation analysis to see the relationship between endogenous variables (Y), exogenous variables $\left(\mathrm{X}_{1}\right)$ and exogenous variables $\left(\mathrm{X}_{2}\right)$. Exogenous Correlation Analysis Bound to Endogenous Variables.

Population that became the focus of this research was the overview area involving subjects or objects that had certain featuresand qualities established by researchers to be calculated and then drawn conclusionswhich amounted to 2,702 respondents. Reachable population was 626 students of $3^{\text {rd }}$ semester ofFEB UHAMKA in 2016.

Table 2. Students Reachable Population of 5 Study Programs of FEB UHAMKA

\begin{tabular}{clcc}
\hline No & \multicolumn{1}{c}{ Study Program } & Number of college students \\
\hline 1 & Accounting & 216 & people \\
2 & Management & 284 & people \\
3 & Taxation (Diploma) & 54 & people \\
4 & Accounting (Diploma) & 27 & people \\
5 & Islamic Economics & 45 & people \\
& TOTAL & 626 & people \\
\hline
\end{tabular}

This research was a sample research. What was meant to generalize was to raise research conclusions as something that applied to the population. A sample with $95 \%$ confidence 
level or $5 \%$ error rate then thenumber of samples could be drawn from the number ofpopulation above was done using Slovin technique which got 244 respondents.

The Results of Statistical Tests. This study consists of three independent variables including Brand Image data $\left(\mathrm{X}_{1}\right)$, Quality of Service $\left(\mathrm{X}_{2}\right)$, and Customer Satisfaction $(\mathrm{Y})$. Data collected from 244 respondents using three test instruments namely Brand Image instruments, Customer Satisfaction, and Instrumentsof Service quality.

(1) Brand Image Data $\left(\mathbf{X}_{1}\right)$. Through data collected from 244 respondents, obtained the score of the range of StudentsSatisfaction was between $54-164$, average (M) of 130.38, standard deviation (SD) of 13.62, mode (Mo) of 128.41, median (Me) of 123.67, and the variance of 185.51. Brand Image $\left(\mathrm{X}_{1}\right)$ data distribution is presented in the following table.

Table 3. Distribution ofScore Frequency of Brand Image $\left(X_{1)}\right.$

\begin{tabular}{cccccc}
\hline $\begin{array}{c}\text { Interval } \\
\text { Class }\end{array}$ & $\begin{array}{c}\text { Middle } \\
\text { Value (Xi) }\end{array}$ & Real Limit & Absolute & $\begin{array}{c}\text { Frequency } \\
\text { Cumulative }\end{array}$ & Relative \\
\hline $54-66$ & 60 & $53.5-66.5$ & 1 & 1 & $0.41 \%$ \\
$68-80$ & 74 & $67.5-80.5$ & 0 & 1 & $0.00 \%$ \\
$81-93$ & 87 & $80.5-93.5$ & 1 & 2 & $0.341 \%$ \\
$94-106$ & 100 & $93.5-106.5$ & 6 & 8 & $2.46 \%$ \\
$107-119$ & 113 & $106.5-119.5$ & 40 & 48 & $16.39 \%$ \\
$120-132$ & 126 & $119.5-132.5$ & 92 & 140 & $37.70 \%$ \\
$133-145$ & 139 & $132.5-145.5$ & 74 & 214 & $30.33 \%$ \\
$146-158$ & 152 & $145.5-158.5$ & 28 & 242 & $11.48 \%$ \\
$159-171$ & 165 & $158.5-171.5$ & 2 & 244 & $0.82 \%$ \\
& TOTAL & & 244 & & $100 \%$ \\
\hline
\end{tabular}

From the distribution of data above, histogram can be presented as follows:

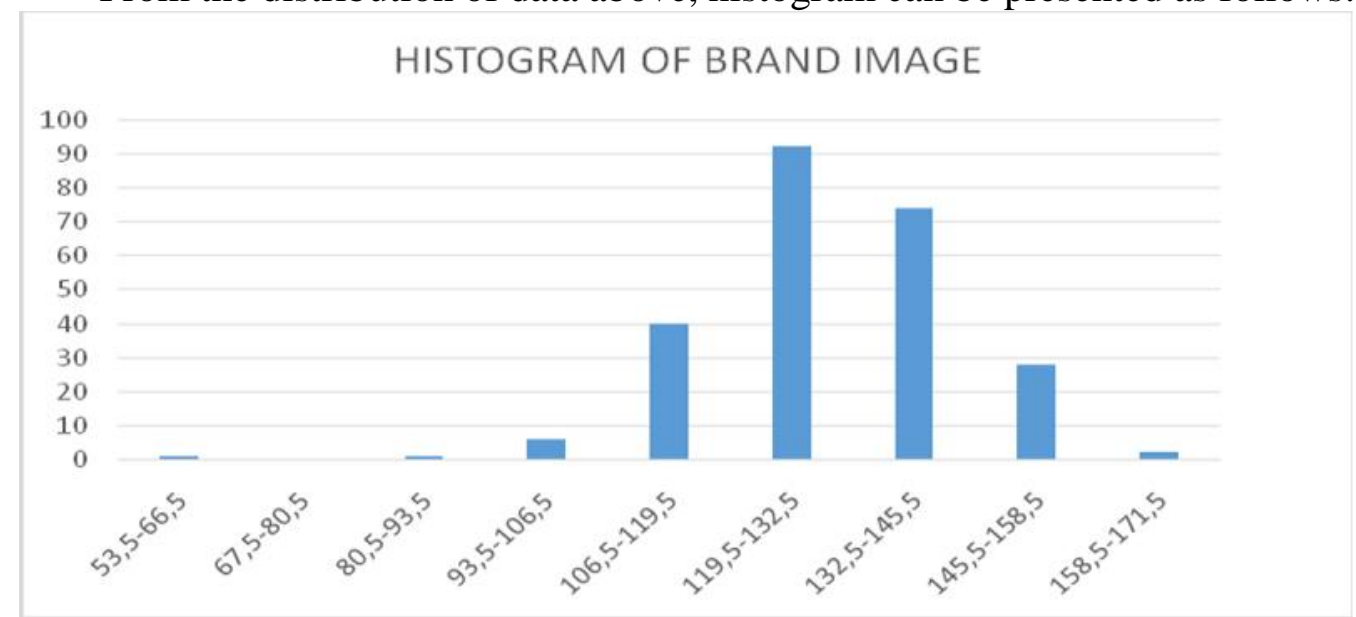

Figure 1. Score Histogram of brand image

From the histogram in the picture above, it is clear that the data is predicted as normal distribution, and it is shown in histogram which tends to be symmetric. Nevertheless, to find out for sure then it is still required to test the data distribution as one of the statistical requirements testing. 
(2) Service Quality Data $\left(\mathbf{X}_{2}\right)$. Through data collected from 244 respondents, the range score of Service quality was between 72 - 172, average (M) of 134.73 , standard deviation (SD) of 16.87, (Mo) mode of 135.16, median (Me) of 139.68, and variance of 294.98. The distribution of Service quality $\left(\mathrm{X}_{2}\right)$ data can be seen in the frequency distribution list below:

Table 4.Distribution of Score Frequency of Service Quality $\left(\mathrm{X}_{2}\right)$

\begin{tabular}{cccccc}
\hline $\begin{array}{c}\text { Interval } \\
\text { Class }\end{array}$ & $\begin{array}{c}\text { Middle } \\
\text { Value (Xi) }\end{array}$ & Real Limit & Absolute & $\begin{array}{c}\text { Frequency } \\
\text { Cumulative }\end{array}$ & Relative \\
\hline $72-83$ & 77.5 & $71.5-83.5$ & 3 & 3 & $1.23 \%$ \\
$84-95$ & 89.5 & $83.5-95.5$ & 4 & 7 & $1.64 \%$ \\
$96-107$ & 101.5 & $95.5-107.5$ & 11 & 18 & $4.51 \%$ \\
$108-119$ & 113.5 & $107.5-119.5$ & 17 & 35 & $6.97 \%$ \\
$120-131$ & 125.5 & $119.5-131.5$ & 61 & 96 & $25.00 \%$ \\
$132-143$ & 137.5 & $131.5-143.5$ & 82 & 178 & $33.61 \%$ \\
$144-155$ & 149.5 & $143.5-155.5$ & 41 & 219 & $16.80 \%$ \\
$156-167$ & 161.5 & $155.5-167.5$ & 21 & 240 & $8.61 \%$ \\
$168-179$ & 173.5 & $167.5-179.5$ & 4 & 244 & $1.64 \%$ \\
& TOTAL & & 244 & & $100 \%$ \\
\hline
\end{tabular}

Based on the data above, histogram of Service quality (X2) can be presented as follows:

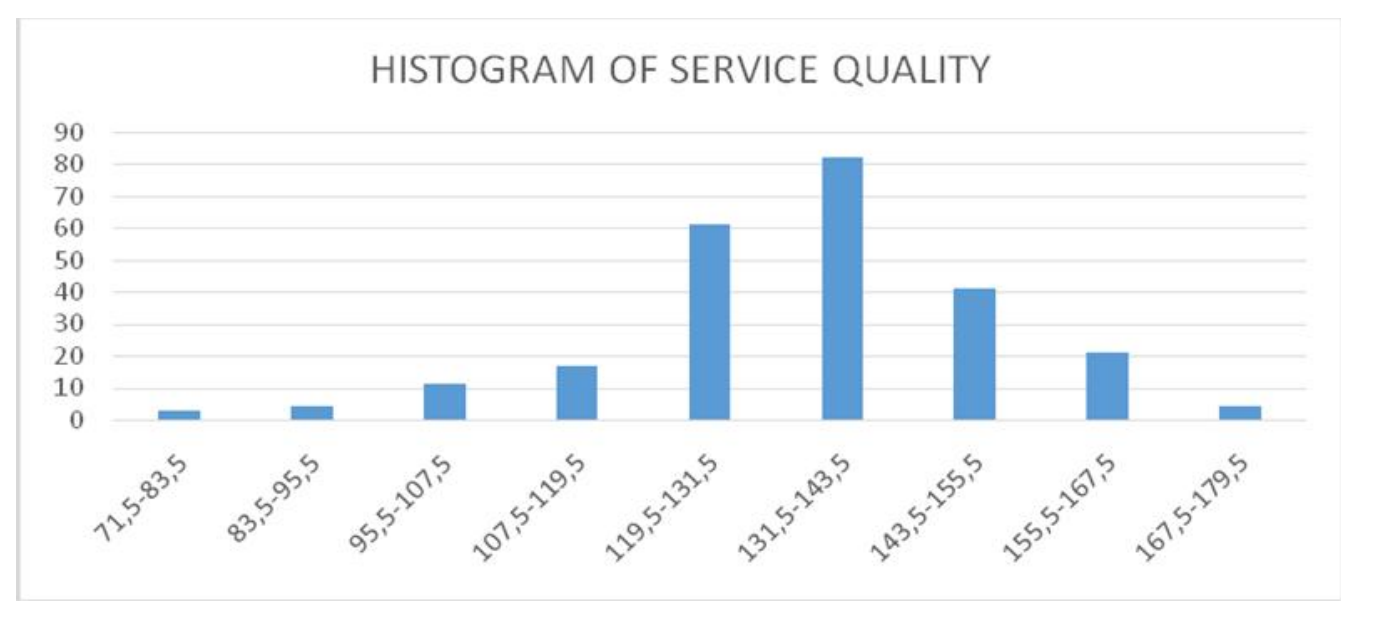

Figure. 2Histogram of Service Quality

From theprevious histogram, it is clear that the Service quality data is predicted to be normally distributed, and shown by a histogram that tends to be symmetric. However, to find out for sure then it is still required to test the data distribution as one of the statistical requirements testing.

(3) Customer Satisfaction Data (Y). Through data collected from 244 respondents, the score of the range of Customer Satisfaction (Y) ranges from $46-165$, it is also obtained an average (M) of 127.63, standard deviation (SD) of 15.59, mode (Mo) of 123.53, median (Me) of 129.93, and variance of 245.96. Data distribution of Customer Satisfaction variable (Y) can be seen in this frequency sharing list:

Table 4.3: Frequency Sharing of Customer Satisfaction Mark(Y) 
Table 5. Distribution of Score Frequency of Customer Satisfaction (Y)

\begin{tabular}{cccccc}
\hline $\begin{array}{c}\text { Interval } \\
\text { Class }\end{array}$ & $\begin{array}{c}\text { Middle } \\
\text { Value }(\mathrm{Xi})\end{array}$ & Real Limit & Absolute & $\begin{array}{c}\text { Frequency } \\
\text { Cumulative }\end{array}$ & Relative \\
\hline $46-59$ & 52.5 & $46.5-59.5$ & 1 & 1 & $0.41 \%$ \\
$60-73$ & 66.5 & $59.5-73.5$ & 0 & 1 & $0.00 \%$ \\
$74-87$ & 80.5 & $73.5-87.5$ & 1 & 2 & $0.41 \%$ \\
$88-101$ & 94.5 & $87.5-101.5$ & 14 & 16 & $5.74 \%$ \\
$102-115$ & 108.5 & $101.5-115.5$ & 28 & 44 & $11.48 \%$ \\
$116-129$ & 122.5 & $115.5-129.5$ & 84 & 128 & $34.43 \%$ \\
$130-143$ & 136.5 & $129.5-143.5$ & 81 & 209 & $33.20 \%$ \\
$144-157$ & 150.5 & $143.5-157.5$ & 29 & 238 & $11.89 \%$ \\
$158-171$ & 164.5 & $157.5-171.5$ & 6 & 244 & $2.46 \%$ \\
& TOTAL & & 244 & & $100 \%$ \\
\hline
\end{tabular}

Based on data above, histogram of Customer Satisfaction (Y) can be prepared as follows:

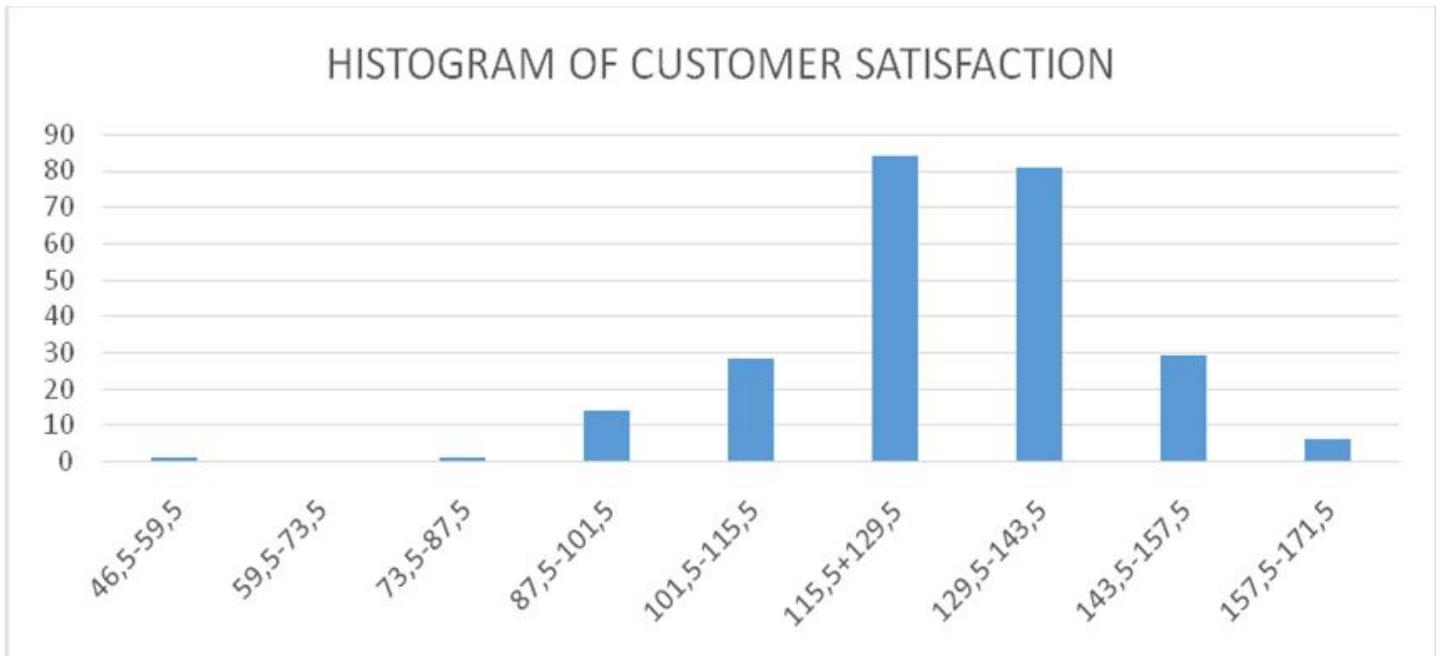

Figure 3. Histogram of Customer Satisfaction

From the histogram, it is clearly visible that data Customer Satisfaction is predicted as normal distribution, and it is shown on histogram which tends to be symmetric. Nonetheless, to find out for sure then it is still required to test the data distribution as one of the statistical requirements testing.

\section{Testing of Requirements Analysis}

1. Normality Test. Normality test of data was done by using SPSS which was through the test of kolmogorovsmirnov normality.

Based on the results of kolmogorovsmirnovnormality test using SPSS, it was known that significance value for brand image was $0.081>0.05$, significance value for service quality was $0.090>0.05$, and value of significance for customer satisfaction was $0.269>0.05$. Hence it can be concluded that residual value for these three variables were normally distributed.

2. Linearity Test. Linearity test is done to know the linearity relationship between variable $\mathrm{Y}$ (customer satisfaction) with variable $\mathrm{X}_{1}$ (band image) and $\mathrm{X}_{2}$ (Quality of Service). Details of each homogeneity test result of the research data are as follows. 
a. Linearity Test between $\mathrm{Y}$ and $\mathrm{X}_{1}$. Calculation result of linearity test of variable $\mathrm{Y}$ with $\mathrm{X}_{1}$ can be seen in table below.From the table above, it is known that Sig value of deviation from linearity was $0.768>0.05$. It can be concluded that there was linear relationship between Customer Satisfaction and Brand Image.

b. Linearity Test between $\mathrm{Y}$ and $\mathrm{X}_{2}$. Result of calculation of linearity test of variable $\mathrm{Y}$ with $\mathrm{X}_{2}$ can be seen in table below.From the results above, it is known that Sig value of deviation from linearity of $0.054>0.05$, it can be concluded that theconnectionofConsumer Satisfaction andService Quality was linear.

From the results of normality test and linearity test above, it has been proved that the data was normally and linearly distributed. Thus, hypothesis testing can be done.

Discussion. Hypothesis testing of this research used regression and correlation formula. The first, second and third hypotheses were analyzed by simple regression and correlation formula. Then the next step wasanalyzing the correlation by using Path Analysis. Details of test results of each hypothesis are as follows.

1. Influence between Brand Image $\left(\mathrm{X}_{1}\right)$ on Customer Satisfaction $(\mathrm{Y})$. The first research hypothesis formula was there is positive influence between Brand Image $\left(\mathrm{X}_{1}\right)$ to Consumer Contentment(Y). That is, if the data of Brand Image is high, then Consumer Contentment $(\mathrm{Y})$ is also high. The results of this study are consistent with previous research from(Ria and Wiryawan, 2012) conducted on Sosro bottles at Pasar Festival Kuningan, Jakarta, and (Iken Mety,2013), at SMAN Jember. Corporate brand image is more influenced by intangible factors i.e. aspects that are more influenced by emotional factors (Sharifah Faridah Syed Alwi 2014).

Details of test results of each hypothesis are as follows.

From the calculation of SPSS, it isknown that the correlation/relationship value $\mathrm{R}$ was equal to 0.818 . From the output obtained coefficient of determination (R square) of 0.667 , this meant that the influence of independent variables (brand image) to the dependent variable (customer satisfaction) was equal to $66.7 \%$. From the output note above, the value of $F_{\text {count }}=487,831$ with a significance level of $0.000<0.05$. Hence, the regression model could be used to predict customer satisfaction variables or in other words there was influence of brand image variable to customer satisfaction variable.

2. Influence between Quality of Service $\left(\mathrm{X}_{2}\right)$ on Customer Satisfaction (Y). The first research hypothesis formula was there is positive influence between Quality of Service $\left(\mathrm{X}_{2}\right)$ to Customer Satisfaction (Y). That is, if the Quality of Service data is high, then Customer Satisfaction (Y) is also high.

The results of this study are consistent with previous research from(Roni Andespa,2017) conducted on padang restaurant customers which presents the design as per customer expectations. Quality or value refers to the nature that describes the good degree of a good or service produced or supplied by a particular Criteria Institution and as something that satisfies the customer and meets their needs and wants (Edward Sallis, 2011).From the calculation, it can be known that the value of correlation/relationship $R$ is equal to 0.845 .From the output obtained coefficient of determination ( $R$ square) of 0.714 , this meant that the impact of independent variables (service quality) to the dependent variable (customer satisfaction) was equal to $71.4 \%$. From the output note above, the value of $\mathrm{F}_{\text {count }}=604.145$ with a significance level of $0.000<0.05$, then the regression model could be used to predict customer satisfaction variables or in other 
words there was influence between service quality variable to customer satisfaction variable.

3. Influence of Brand Image $\left(\mathrm{X}_{1}\right)$ with Quality of Service $\left(\mathrm{X}_{2}\right)$ on Customer Satisfaction (Y).The first research hypothesis formula was there is positive influence between Brand Image $\left(\mathrm{X}_{1}\right)$ and Quality of Service $\left(\mathrm{X}_{2}\right)$ to Customer Satisfaction $(\mathrm{Y})$. The result of this research is consistent with previous research conducted by (Iken Mety,2013) which stated that there is influence of brand image and prospective location which make continuity study in a university. And it is also accordance with (Puti Ara Zena, 2013) which states there is a relationship between Marketing, Quality of Service to customer satisfaction, and Customer Loyalty. Customer satisfaction is the feeling of pleasure or disappointment of a person by comparing between products/services expected and products/services received. (Kotler, 2011). One of the factors that determine customer satisfaction is the perception of the customer regarding the quality of services, products, prices and factors that are personal and temporal situation (Rangkuti, 2011).That is, if the data of Brand Image and Quality of Service is high, then Customer Satisfaction (Y) is also high. From the calculation obtained that the value of Sig. F Change $=0,000$ $<0.05$, it can be concluded that brand image variable and service quality variable were simultaneously related to customer satisfaction variable. From the above data also obtained $\mathrm{R}$ value of 0.884 which meant the relationship degree of brand image and service quality to customer satisfaction is a perfect correlation category. From the table above, the value of correlation/relationship $\mathrm{R}$ was equal to 0.884 . From the output obtained coefficient of determination ( $\mathrm{R}$ square) of 0.781 , this meant that the influence of independent variables (brand image and service quality) to the dependent variable (customer satisfaction) was $78.1 \%$.

Research conducted can be presented in the research findings as follows.

1. Based on simple regression equation of $X_{1}$ to $Y$, there is a positive and significant influence between brand images $\left(\mathrm{X}_{1}\right)$ on Customer Satisfaction $(\mathrm{Y})$.

2. Based on the simple regression equation $\mathrm{X}_{2}$ to $\mathrm{Y}$, there is a positive and significant influence between service qualities $\left(\mathrm{X}_{2}\right)$ on Customer Satisfaction $(\mathrm{Y})$.

3. Based on simple regression equation $\mathrm{X}_{1}$ with $\mathrm{X}_{2}$ to $\mathrm{Y}$, there is positive and significant influence between brandsimages $\left(\mathrm{X}_{1}\right)$ with service quality $\left(\mathrm{X}_{2}\right)$ on Customer Satisfaction (Y).

Although the research on the Influence of Brand Image and Quality of Service on Customer Satisfaction at Faculty of Economics and Business UHAMKA had been strived to follow the exact procedures possible in the implementation from the beginning until the presentation of research report, it still had weaknesses that were recognized as the weakness of this study. Of course the authors hope the results of this study can be refined by other researchers who examine with the same title. The author realizes that the limitations of this study include: First. Before doing the research the author had conducted a series of trials to obtain valid and reliable instrument.However, the collection through this questionnaire still had weaknesses such as less and dishonest answers, and questions which were incomplete or poorly understood by the respondents.

Second. The author had limitations in conducting research review, less knowledge, less literature, less time and effort and also less cost in this research.

Third. Despite the shortcomings yet the results of this research has provided very important information for the development of Faculty of Economics and Business 
UHAMKA that there is a direct and significant influence between Brand Image $\left(\mathrm{X}_{1}\right)$ and Quality of Service $\left(\mathrm{X}_{2}\right)$ on Customer Satisfaction (Y).

Fourth. Selection of populations and samples that may not correspond to the desired proxies in the study might lead to bias. This study only involved students as a proxy of decision making. Subsequent research needs to use population and sample of the actual decision makers (Dean, Leader of Study program) as its sampling.

Fifth. Instruments containing some cases in this study were still not well understood by the respondents (Students), so for further research it is necessary to make other instruments more easily understood by the respondents.

Sixth. This research had not been explored further about the advantages and disadvantages of each indicator in the variable. So, it had not been able to see on which variable perceived part either as the superiorityor as the weakness of each variable.

\section{ENDING}

Conclusion. This research aims to observe the positive and significant effect of brand image and quality of education service to customer satisfaction by using hypothesis test of each variable and path analysis.

The results showed that there was a positive and significant impact of Brand Image on Customer Satisfaction of $66.7 \%$. This means that every addition of $1 \%$ on brand image value, then the value of customer satisfaction will increase 0.781 . Since the regression coefficient is positive, it can be concluded there is a positive influence between variable $\mathrm{X}_{1}$ to variable $\mathrm{Y}$. From the regression analysis obtained that the effect of brand image $\left(\mathrm{X}_{1}\right)$ on customer satisfaction $(\mathrm{Y})$ is depicted with the equation $\mathrm{Y}=22.453+0.781 \mathrm{X}_{1}$. From the equation can be concluded that for the coefficient of $\mathrm{X}_{1}$ of 0.781 , states every addition of $1 \%$ on brand image value, then the value of customer satisfaction will increase 0.781

Suggestion. First, in order to encourage the achievement of the level of customer satisfaction, the Faculty should pay attention to the expectations and complaints of its customers, and continue to improve the quality of education services. Second, the Party is advised to pay attention to the results obtained from this research. Third, the test of this brand image model does not involve marketing mix variables as a brand builder, it is suggested to future researchers to include marketing mix variables as exogenous variables in influencing brand image.

\section{REFERENCES}

Agata, Pradela (2015). Quality of graduates' preparation forlabour market-a ServQual Analysis, Procedia - Social and Behavioral Sciences 174, 1671-1677.

Andre, Daniel dan Fredella. (2015). "Student Satisfaction with the Image of HigherEducation and Complaints and Its Implications for Loyalty". Business Management Scientific Journal, 15 (2), July-December 2015. doi: 10.5296 / bms.v5i2.6003. URL: http://dx.doi.org/10.5296/bms.v5i2.6003.

AlifFianto, et al.(2014). “The Influence of Brand Image on Purchase Behaviour Through Brand Trust”. Journal Business Management and Strategy, ISSN 2157-6068, 
2014, 5 (2) doi:10.5296/bms.v5i2.6003 URL:

http://dx.doi.org/10.5296/bms.v5i2.6003.

Asghar Afshar Jahanshahi (2011). "Study the Effects of Customer Service and Product Quality on Customer Satisfaction and Loyalty", International Journal of Humanitiesand Social Science, 1 (7), Special Issue -June 2011.

Danim, Sudarman (2007) in School System 20/20 Transforming Teacher (2013), NewVision of School Management, Jakarta: BumiAksara.

DesyIrana and Rahmat Hidayat (2017). "The Influence of Brand and Price Image on Purchasing Decision at Institute of Management Sukma”, Jurnal Ilmiah, 5 (1), 1524,,ISSN-2355-1488 URL: http://jurnal.stimsukmamedan.ac.id/index.php/ilman.

Dudung Juhana and Ali Mulyawan, (2015). "Effect of Quality of Educational ServiceServices on Student Satisfaction at STMIK Mardira Indonesia Bandung". Jurnal Ekonomi, Bisnis\& Entrepreneurship, 9 (1), 1-15. ISSN 2443-0633.

DesyIranaDewiLubis and RahmatHidayat (2017), "Effect of Brand Image and Price on Purchasing Decisions at the Sukma Medan College of Management Sciences. Ilman Journal, 5 (1), 15-24, February 2017, ISSN 2355-1488

http://jurnal.stimsukmamedan.ac.id/index.php/ilman16.

Goetsch dan David. (2016). Quality Management for Organizational Excellence: Introduction to Total Quality, 8 th Edition. ISBN-13:9780133791853.

Halim (2014). School and Community Based Management: Winning Competation Quality Strategy. Jakarta: PT. RakartaSamarta.

IkenMetyWulandari (2013). The Effect of Brand Image And Location ProspectiveStudents Making Continuing In Studies University.URL: http://repository.unej.ac.id/handle/123456789/6778.

Indrajit, Ricardus Eko, (2013). Lima DimensiPerguruan Tinggi. I EKOJI 999 nomer 413, Oktober 2013.

Kotler, Philip, dan Gary Amstrong. (2011). Dasar-Dasar Pemasaran, Edisi Bahasa Indonesia. Bandung: Prehalindo.

Kotler, P., \& Keller, K. L. (2012). Marketing Management (14th ed.). New Jersey:Pearson Prestice Hall.

Nenden, Nuraedi, Taufan (2016). "Pengaruh Kualitas Jasa Pendidikan Terhadap kepuasan Mahasiswa di Universitas Pendidikan Indonesia", Jurnal ADPEND, 1 (1).14128152e.2580-1007

NurdinHidayah, Diana Sari and AriefHelmi.(2013).“The Relationship Between the Customer Value And Satisfaction To Advocacy Behavior. The Empirical Study in Higher Education". VSRD International Journal of Business and Management Research, III (VIII) August 2013 / 303e-ISSN: 2231-248X, p-ISSN: 2319-2194 (C) VSRD International Journals Website: www.vsrdjournals.com.

Nuridin (2018). "Effect of Service Quality and Quality of Products to Customer loyalty with Customer Satisfaction as Intervening Variable in PT. Nano Coating Indonesia", International Journal of Business and Applied Social Science (IJBASS), 4 (1), Januari 2018 E-ISSN: 2469-6501 URL: http://ijbassnet.com/.

Peter,Halim. (2014 ). "The Influence of Product Quality, Brand Image, and Quality of Service to Customer Trust and Implication on Customer Loyalty", European Journal of Business and Management, 6 (29), ISSN 2222-1905 (Paper) ISSN 2222-2839 (Online) 
Patel and Patel. (2012). "Effect of Brand Image and Price on Purchasing Decisions at the Sukma Medan College of Management ". Ilman Journal, 5 (1), 15-24, February 2017, ISSN 2355-1488

PA Zena, AD Hadisumarto (2013). "The Study of Relationship among Experiential Marketing, Service Quality, Customer Satisfaction, and Customer Loyalty". Journal of Asian Marketing. amj@ui.ac.id, amj.ema.feui@gmail.com; harryadin.mahardika@ui.ac.id.Puti Ara Zena, Aswin Dewanto Hadisumarto PA Zena, AD Hadisumarto - Asean marketing journal, 2013- journal.ui.ac.id.

Rangkuti, Freddy. (2011). The Power of Brand. Jakarta: PT. GramediaPustakaUtama. (Revised Editions).

Ria E.Monarch \& Zahrida Z. Wiryawan, (2012). "Influence brand awareness' against perceived quality and brand loyalty as determinant against purchase intention", Jurnal Manajemen, XVI (03), Oktober, ISSN 1410-3583. URL: http://ecojoin.orgEmail: submisipaper@gmail.com

Rivo Christian Kumowal, (2016), "The Effect of store Brand Image and Service Quality to wards Customer Loyalti at Freshmart Superstore Manado", Journal EMBA, 4 (1) Maret, 306-314 ISSN 2303-1174. URL: www.google.com. Email: rckumowal@gmail.com.

Roni Andespa (2017). Creating Customer Satisfaction and Loyalty with Product Design Expected by Customer Riau Economic Institute (STIER).

Riyadi (2011). Total Quality Management IN Education. Edisi Bahasa Indonesia, Jogjakarta: IRCiSoD, Cet. 2, Maret.

Rossi, P., Adilson, B., \&Bakpayev, M. ( 2015). "Private labels versus national brands: The effects of branding on sensory perceptions and purchase intentions". Journal of Retailing and Consumer Services, 27, 74-79.

Shammot, M. M. (2011). Factors Affecting the J ordanian Students' Selection, Decision Among Private Universities. Journal of Business Studies Quarterly, 2(3), 57-63.

Sharifah Faridah Syed Alwi a, Philip J. Kitchen b.(2014). "Projecting corporate brand image and behavioral response in business schools: Cognitive or affective brand attributes?" , Journal of Business Research, 67, 2324-2336.

Spears, Nancy Spears and Sighn, S.N. (2011). "Measuring attitude to word the brand andpurchase intentions". Journal of Current Issue and Reaserch in Advertising, 26, 53-66. . (Revised Editions).

Yani, Yanuar (2013). Study of Factors Affecting Students Continuing Study at Kuningan University. (Revised Editions).

Zamroni. (2011). Dynamics of Quality Improvement. Yogyakarta: Gavin Kalam Utama. 